\title{
Coefficient of Variation Can Identify the Most Important Effects of Experimental Treatments
}

\author{
José Carlos LORENZO ${ }^{1 *}$, Lourdes YABOR ${ }^{1}$, Norma MEDINA $^{2}$, \\ Nicolás QUINTANA², Vanessa WELLS ${ }^{3}$ \\ ${ }^{1}$ University of Ciego de Ávila, Bioplant Centre, Laboratory for Plant Breeding. Ciego de Ávila 69450, \\ Cuba;jclorenzo@bioplantas.cu("correspondingauthor); lyabor@bioplantas.cu \\ ${ }^{2}$ University of Ciego de Avila, Ciego de Avila69450,Cuba;nmedina@unica.cu;nquintana@unica.cu \\ ${ }^{3}$ The University of Sydney, Faculty of Agriculture and Environment, Plant Breeding Institute, Australia; vanessa.wells@sydney.edu.au
}

\begin{abstract}
Most agricultural experiments involve evaluation of multiple variables and at times it can be difficult to identify the biologically relevant effects of the experimental treatments after performing the traditional ANOVA, Tukey and $\mathrm{t}$-tests. The coefficient of variation formula could be an important tool to focus 'Result and Discussion' sections only on the most important changes produced by the experimental treatments. This short report is intended to exemplify the use of the coefficient of variation in three plant physiology experiments. The first one dealt with the effects of common bean plantlet exposure to high temperature under controlled conditions (levels: 28 and $40{ }^{\circ} \mathrm{C}$ ). The second experiment was related to common bean seed exposure to liquid nitrogen during five different periods of time (levels: 0, 7, 14, 21 and 28 days). The third experiment was bi-factorial: factor 1 was the 'type of plant material' (levels: pineapple plants genetically transformed and the untransformed control); and factor 2 was the 'time of in vitro-plantlet hardening' (levels: 0, 15 and 30 days). Contents of phenolics, aldehydes, chlorophylls and proteins were determined. Percentage of seed germination, electrolyte leakage, peroxidase activity, plant height and weight were also measured. Experiments were monofactorial with two levels, monofactorial with five levels and bifactorial, respectively, with randomized design. The coefficient of variation showed that the most remarkable effects of high temperature were recorded in free phenolics and chlorophylls $(a, b$, total). Electrolyte leakage and chlorophyll $b$ concentration were the most modified indicators as a result of seed exposure to liquid nitrogen. In the third experiment, modification in the levels of malondialdehyde and other aldehydes were the most relevant changes resulting from factors interactions. A similar procedure has not been published, except for our previous publications, not focused on the use of the coefficient of variation, just on the biological results.
\end{abstract}

Keywords: abiotic stress, Ananas comosus, biochemical markers, biostatistics, genetic transformation, OCV, Phaseolus vulgaris

\section{Introduction}

Most agricultural experiments involve evaluation of multiple variables such as yield, plant height, biochemical indicators, etc. After performing, for instance the traditional ANOVA, Tukey and t-tests, it is sometimes difficult to identify the most relevant effects of the experimental treatments from the biological point of view. We believe the coefficient of variation formula could be an important tool to focus 'Result and Discussion' sections only on the most important changes produced during the experiment.

The coefficient of variation is calculated as the rate: (Standard deviation/Average) ${ }^{*} 100$, and measures the variability of a series of numbers independently of the unit of measurement used for these numbers. In order to do so, the coefficient of variation eliminates the unit of measurement of the standard deviation of a series of numbers by dividing it by the mean of these numbers. The coefficient of variation can be used to compare distributions obtained with different units, such as, for example, cm, mg and kg/ha (Abdi, 2010; Ivanov, 1989).

The present short report is intended to exemplify the use of the coefficient of variation formula, in an untraditional way, in three plant physiology experiments. Our method is untraditional because the original figures we used to calculate the coefficient of variation are the averages of each treatment. In the present paper, we called this rate as Overall Coefficient of Variation (OCV). We are not trying to convince statisticians about any new method; rather, we would like practicing scientists to consider in their research the coefficient of variation as described here. Although we have 
288

performed a comprehensive literature search, we have not found any procedure similar and simpler to the one described in this paper, except for our previous publications (Cejas et al., 2012; Gomez-Pando et al., 2009; González et al., 2010; González et al., 2013; Pérez et al., 2013; Pérez et al., 2012; Zevallos et al., 2013a; Zevallos et al., 2013b), not focused on the use of statistical or mathematical methods, just on the results.

\section{Materials and methods}

The first experiment was related to the effects of high temperature on levels of phenolics, aldehydes and chlorophylls in common bean plantlets (cv. 'Milagro Villaclareño'). After harvesting, seeds were stored at $4^{\circ} \mathrm{C}$ in the dark, in hermetically closed containers. Seeds with $12 \%$ moisture content, based on fresh weight (ISTA, 2005), were used in this experiment. Seeds were allowed to germinate and grow without high temperature stress $\left(28^{\circ} \mathrm{C}\right)$ during 10 days, and then plantlets were exposed to $40{ }^{\circ} \mathrm{C}$ during 9.3 hours ( $50 \%$ plant survival was previously observed after $9.3 \mathrm{~h}$ of heat treatment; unpublished data). A control treatment $\left(28^{\circ} \mathrm{C}\right)$ was established. Each plant container $\left(200 \mathrm{~cm}^{3}\right.$ of Ferralitic red soil) was irrigated daily with $25 \mathrm{ml}$ water. Each treatment involved five plant containers and three seeds per container were sown. At 9.3 hours of stress, middle-aged leaves of each plant container were collected, pooled and ground in liquid nitrogen to produce leaf powder. Three independent samples (1000 mg powder each) per treatment were used to perform every biochemical measurement. Levels of chlorophylls $(a, b$, total), phenolics (free, cell wall-linked, total), and malondialdehyde and other aldehydes were determined according to the methods of Porra (2002), Gurr et al. (1992) and Heath and Packer (1968), respectively. Results of this experiment are unpublished.

In the second experiment, common bean seeds obtained as described above, were placed in cryo-vials (volume: $5 \mathrm{ml} ; 12$ seeds per cryo-vial) and immersed in liquid nitrogen for 7, 14, 21 or 28 days. Control seeds were set to germinate or analyzed directly, without liquid nitrogen exposure. Recovery of seeds from liquid nitrogen was performed according to Standwood and Bass (1981). To evaluate germination rate, seeds (three replicates of 10 seeds per treatment) were placed on filter paper moistened with $25 \mathrm{ml}$ distilled water (pH 6.8) for 5 days (dark, $27 \pm 1^{\circ} \mathrm{C}$ ) in Petri dishes (Ø: $100 \mathrm{~mm}$ ). For biochemical determinations, independent samples of 25 seeds each, recovered from liquid nitrogen according to Standwood and Bass (1981), were ground in liquid nitrogen to produce seed powder. Three independent samples $(1000 \mathrm{mg}$ powder each) were used to perform every biochemical measurement. Levels of chlorophylls $(a, b$, total), phenolics (free, cell walllinked, total), malondialdehyde, other aldehydes, proteins (Bradford, 1976) and peroxidase activity (Hammerschmidt $e t$ al., 1982) were determined. Enzyme activity was also expressed on the basis of protein as specific activity. The electrolyte efflux test was used for electrolyte leakage determination (Martínez-Montero et al., 2002) from intact seeds (3 replicates of 15 seeds each per treatment). Fifteen seeds were incubated in $20 \mathrm{ml}$ double-distilled water. Conductivity of the water was measured before $(\mathrm{C} 0)$ and after 20 hours of imbibitions (C). Samples were then autoclaved $\left(30 \mathrm{~min}\right.$ at $112^{\circ} \mathrm{C}, 107 \mathrm{kPa}$ ) and cooled down to room temperature $\left(25^{\circ} \mathrm{C}\right)$ for 4 hours to determine the total conductivity (Ctotal). The percentage of electrolyte leakage was calculated from the ratio: $(C-C 0)^{*} 100 /($ Ctotal $-C 0)$. Results of this experiment are unpublished.

In the third experiment, pineapple transgenic plantlets were obtained according to Espinosa et al. (2002). Agrobacterium tumefaciens (strain AT2260, pHCA58, bar gene controlled by maize Ubi 1 promoter, class-I bean chitinase gene controlled by a hybrid OCS-35S CaMV-rice actin I promoter, tobacco ap24 gene controlled by $35 \mathrm{~S}$ CaMV promoter) was used to transformed embryogenic calli. Phosphinotricin-resistant plantlets were recovered. Nontransformed plantlets (control treatment) were obtained following the protocol described above but avoiding contact with Agrobacterium tumefaciens and phosphinotricin. Sixty non-transformed and 60 transformed (one clone) plantlets were transferred to a greenhouse for hardening according to Yanes et al. (2000): plastic trays, substrate: zeolite+filter cake (1:1), substrate/plant: $82 \mathrm{~cm}^{3}$, microject automated irrigation for $25 \mathrm{~s}$ every $30 \mathrm{~min}$ and illumination: $800 \mu \mathrm{mol} \mathrm{m} \mathrm{m}^{-2} \mathrm{~s}^{-1}$. Evaluations were made at 0,15 and 30 days of hardening. The experimental design was completely randomized. Plant height and weight were recorded. Leaf samples were stored in liquid nitrogen until biochemical analysis. Each biochemical determination started from three independent pooled samples (100 mg each). They were finely grounded in liquid nitrogen. Contents of malondialdehyde and other aldehydes, chlorophyll $(a, b)$, and phenolics (free and cell wall-linked) were measured. Results of this experiment were previously published by Yabor et al. (2006).

The SPSS (version 8.0 for Windows, SPSS Inc., New York, $\mathrm{NY}$ ) was used to perform $\mathrm{t}$-tests in the first experiment, and One- and Two Way ANOVA and Tukey tests $(\mathrm{p}=0.05)$ in the second and the third experiments, respectively. The OCV were calculated as the rate: (Standard deviation/Average)* 100 . To calculate this coefficient, average values of the treatments, or experimental factors, were considered. OCV were classified in "high", "medium" or "low", which is explained in each table footnotes. (Max OCV recorded - Min OCV recorded) / 3 produced the class width.

\section{Results and discussion}

As far as 'Results' are concerned, in the first experiment, according to the outcome of the t-tests, statistically significant differences between treatments were observed in every single biochemical indicator evaluated (Fig. 1). To know which indicators were more affected by high temperature stress, the OCV were calculated and classified as "high", "medium" and "low". The OCV showed that the most remarkable effects of high temperature were recorded in free phenolics and chlorophylls ( $\mathrm{a}, \mathrm{b}$, total). We therefore would suggest plant physiologists to focus their attention on these four biochemical indicators. The effect of high temperature stress was found to be "medium" on cell wall-linked and total phenolics, as well as on other aldehydes. The influence of heat stress on malondialdehyde levels was classified as "low".

Table 1 shows the effects of the second experiment. Electrolyte leakage and chlorophyll $b$ concentration were the most modified indicators by the different times of seed exposure 

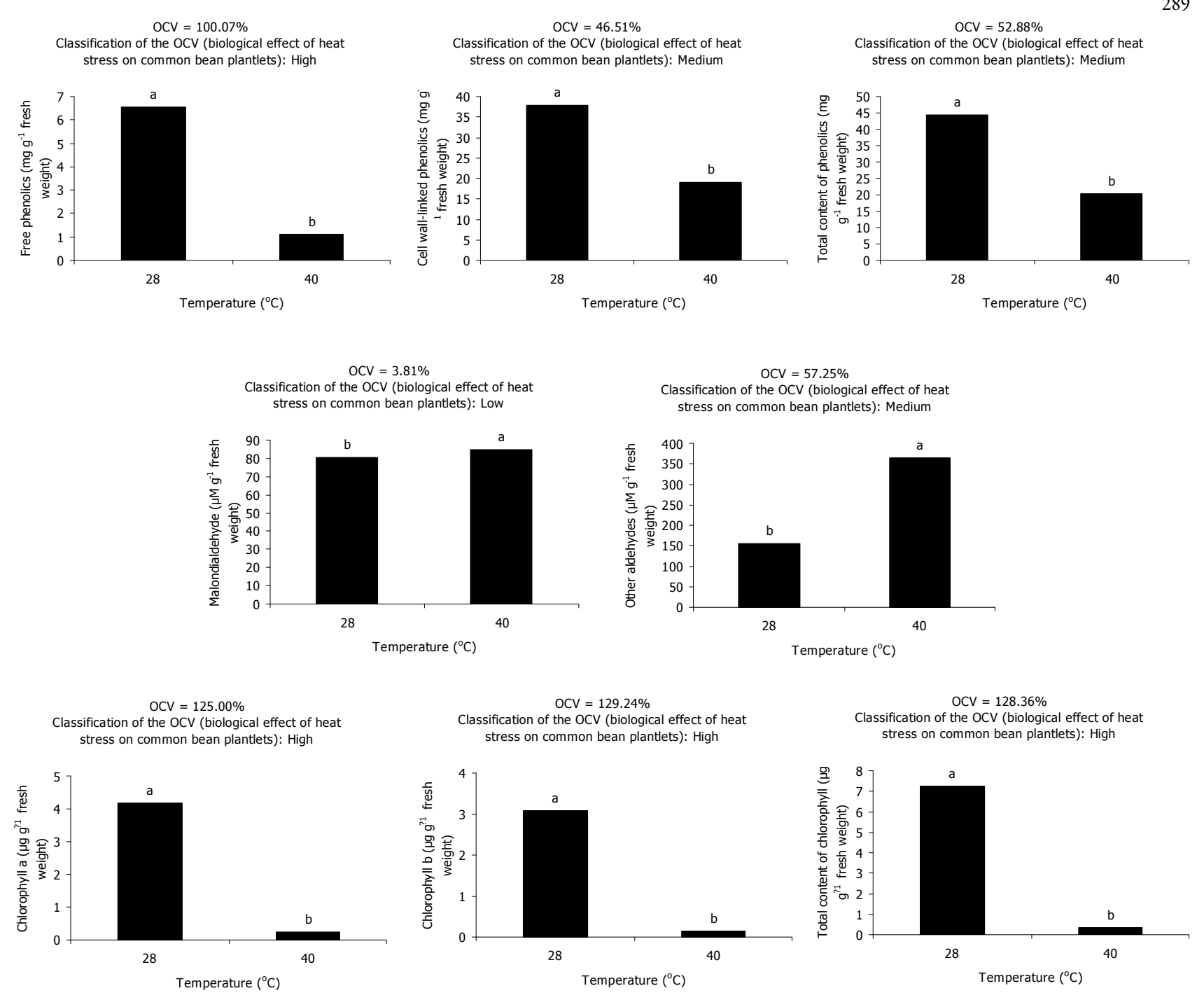

Fig. 1. Effect of exposure to high temperature on common bean plantlets at 9.3 hours of stress. Indicators were evaluated in middle-aged leaves. In each panel, different letters above the bars indicate that differences are statistically significant $(\mathrm{t}$-test, $\mathrm{p} \leq 0.05)$. Overall coefficient of variation $=($ Standard deviation/Average) ${ }^{*} 100$. To calculate this coefficient, average values of the two conditions compared were considered. The higher difference between the two averages compared, the higher the overall coefficient of variation. $\mathrm{Min}$ OCV recorded $=3.81 \% ; \mathrm{Max}$ OCV recorded $=129.24 \%$; $\mathrm{Max}-\mathrm{Min}=$ 125.43\%; (Max - Min) / 3 = 41.81\%. Classification of the OCVs: "low" from 3.81 to 45.62\%; "medium" from 45.62 to 87.43\% and "high" from 87.43 to $129.24 \%$.

Table 1. Biochemical changes produced in common bean seeds after different times of exposure to liquid nitrogen

\begin{tabular}{|c|c|c|c|c|c|c|c|}
\hline Seed exposure to liquid nitrogen (days) & 0 & 7 & 14 & 21 & 28 & OCV (\%)" & $\begin{array}{l}\text { Classification of the OCV (biological effect of } \\
\text { the time of exposure to liquid nitrogen) }\end{array}$ \\
\hline Percentage of germination at 5 days after exposure to $\mathrm{LN}^{*}$ & $93.33 \mathrm{a}$ & $93.33 \mathrm{a}$ & $93.33 \mathrm{a}$ & $86.67 \mathrm{a}$ & $86.67 \mathrm{a}$ & 4.03 & Low \\
\hline Electrolyte leakage (\%)* & $0.49 \mathrm{~b}$ & $2.99 \mathrm{~b}$ & $25.68 \mathrm{a}$ & $26.78 \mathrm{a}$ & $29.15 \mathrm{a}$ & 82.45 & High \\
\hline Chlorophyll a concentration ( $\mu \mathrm{g} \mathrm{g}^{-1}$ fresh weight $)^{*}$ & $5.81 \mathrm{ab}$ & $7.14 \mathrm{ab}$ & $10.16 \mathrm{a}$ & $3.90 \mathrm{~b}$ & $3.31 \mathrm{~b}$ & 45.33 & Medium \\
\hline Chlorophyll b concentration $\left(\mu g^{-1} \text { fresh weight }\right)^{*}$ & $4.70 \mathrm{~b}$ & $4.13 \mathrm{~b}$ & $10.87 \mathrm{a}$ & $3.46 \mathrm{~b}$ & $1.69 \mathrm{~b}$ & 70.15 & High \\
\hline Total chlorophyll concentration ( $\mu \mathrm{g} \mathrm{g}^{-1}$ fresh weight $)^{*}$ & $10.51 \mathrm{~b}$ & $11.26 \mathrm{~b}$ & $21.02 \mathrm{a}$ & $7.36 \mathrm{~b}$ & $5.01 \mathrm{~b}$ & 55.51 & Medium \\
\hline Content of free phenolics ( $\mu \mathrm{g} \mathrm{g}^{-1}$ fresh weight) & $326.71 \mathrm{~b}$ & $347.75 \mathrm{~b}$ & $332.54 \mathrm{~b}$ & $614.90 \mathrm{a}$ & $88.38 \mathrm{c}$ & 54.53 & Medium \\
\hline Content of cell wall-linked phenolics ( $\mu \mathrm{g} \mathrm{g}^{-1}$ fresh weight) ${ }^{*}$ & $7243.31 \mathrm{~b}$ & $7295.57 \mathrm{~b}$ & $7486.11 \mathrm{~b}$ & $7594.70 \mathrm{~b}$ & $9473.48 \mathrm{a}$ & 11.97 & Low \\
\hline Total content of phenolics ( $\mu \mathrm{g} \mathrm{g}^{-1}$ fresh weight $)^{*}$ & $7570.02 \mathrm{~b}$ & $7643.32 \mathrm{~b}$ & $7818.65 b$ & $8209.60 \mathrm{~b}$ & $9561.87 a$ & 10.07 & Low \\
\hline Malondialdehyde content ( $\mu \mathrm{mol} \mathrm{g}^{-1}$ fresh weight $)^{*}$ & $185.73 \mathrm{a}$ & $190.96 \mathrm{a}$ & 136.69 a & $169.74 \mathrm{a}$ & 119.26 a & 19.50 & Low \\
\hline Other aldehyde content ( $\mu \mathrm{mol} \mathrm{g}^{-1}$ fresh weight $)^{*}$ & $5.40 \mathrm{a}$ & $5.05 \mathrm{a}$ & $3.97 \mathrm{a}$ & $5.14 \mathrm{a}$ & $4.15 \mathrm{a}$ & 13.44 & Low \\
\hline Total protein content $\left(\mathrm{mg} \mathrm{g}^{-1} \text { fresh weight }\right)^{*}$ & $29.45 \mathrm{ab}$ & $29.34 \mathrm{ab}$ & $28.74 \mathrm{~b}$ & $31.07 \mathrm{a}$ & 30.89 a & 3.44 & Low \\
\hline Peroxidase activity $\left(\mathrm{U} \mathrm{mg}^{-1} \text { fresh weight }\right)^{*}$ & $52.91 \mathrm{a}$ & $68.47 a$ & $81.35 \mathrm{a}$ & $74.21 \mathrm{a}$ & $67.91 \mathrm{a}$ & 15.20 & Low \\
\hline Peroxidase specific activity $\left(\mathrm{U} \mathrm{mg}^{-1} \text { of protein }\right)^{*}$ & $1.80 \mathrm{a}$ & $2.32 \mathrm{a}$ & $2.83 \mathrm{a}$ & $2.39 \mathrm{a}$ & $2.20 \mathrm{a}$ & 16.18 & Low \\
\hline
\end{tabular}

${ }^{*}$ Results with the same letter are not statistically different (One-Way ANOVA, Tukey, $\mathrm{p}>0.05$ ).

${ }^{* *}$ Overall coefficient of variation $=(\text { Standard deviation/Average })^{*} 100$. To calculate this coefficient, average values of the five treatments compared were considered.

The higher difference between the five averages compared, the higher the overall coefficient of variation.

${ }_{* * *}$ Min OCV recorded = 3.44\%; Max OCV recorded = 82.45\%; Max - Min = 79.01\%; (Max - Min) / $3=26.34 \%$. Classification of the OCVs: "low" from 3.44 to $29.78 \%$; "medium" from 29.78 to $56.11 \%$ and "high" from 56.11 to $82.45 \%$. 
Table 2. Effects of two experimental factors, "type of plant material" and "time of in vitro-plantlet hardening", on plant height and weight and levels of malondialdehyde, other aldehydes, chlorophyll pigments (a, b) and phenolics (free, cell wall-linked). NTP: Non-transformed plantlets. TP: Transformed plantlets. Results of this experiment were previously published by Yabor et al. (2006)

\begin{tabular}{|c|c|c|c|c|c|c|c|c|c|c|c|c|c|c|c|c|c|}
\hline & \multicolumn{8}{|c|}{ Effectoffactorsinteraction) } & \multicolumn{4}{|c|}{ Effect of the factor " "typeof plantmaterial" } & \multicolumn{5}{|c|}{ Effectof the factor " imme of imvito-phandethardening" } \\
\hline & \multicolumn{2}{|c|}{0 dayofhardening } & \multicolumn{2}{|c|}{15 daysofhardening } & \multicolumn{2}{|c|}{30 daysofhardening } & \multirow{2}{*}{$\begin{array}{l}\text { OCV } \\
(\%)^{-}\end{array}$} & \multirow{2}{*}{$\begin{array}{l}\text { Chassification of } \\
\text { the OCV } \\
\text { (effectofffactors } \\
\text { interaction) })^{-}\end{array}$} & \multirow[b]{2}{*}{ NTP } & \multirow[b]{2}{*}{ ТP } & \multirow{2}{*}{$\begin{array}{l}\text { OCV } \\
(\%)^{\circ}\end{array}$} & \multirow{2}{*}{$\begin{array}{l}\text { Clasification of } \\
\text { the OCV (effect } \\
\text { of the factor "type } \\
\text { of plantmaterial" }\end{array}$} & \multicolumn{3}{|c|}{ Days of hardening } & \multirow{2}{*}{$\begin{array}{l}\text { OCV } \\
(\%)^{\circ}\end{array}$} & \multirow{2}{*}{$\begin{array}{l}\text { Classificationof the } \\
\mathrm{OCV} \text { (effectof the } \\
\text { factor "timeofin } \\
\text { vitho-plantet } \\
\text { hardening")- }\end{array}$} \\
\hline & NTP & $\mathrm{TP}$ & NTP & TP & NTP & TP & & & & & & & 0 & 15 & 30 & & \\
\hline Plantheight( (cm) & $16.5 c$ & $15 . \%$ & $182 \mathrm{~b}$ & $18.8 \mathrm{~b}$ & $197 \mathrm{a}$ & $19.6 a$ & 880 & Low & 18.13 & 18.10 & 0.13 & Low & 1620 & 1850 & 19.65 & 9.70 & Low \\
\hline Plantweight(g. & $15.15 \mathrm{c}$ & $15.63 \mathrm{c}$ & $21.45 \mathrm{~b}$ & $21.94 \mathrm{~b}$ & $25.51 \mathrm{a}$ & $25.43 a$ & 21.87 & Low & 20.70 & 21.00 & 1.01 & Low & 1539 & 21.70 & 25.47 & 2442 & Low \\
\hline $\begin{array}{l}\text { Malondialdehyde } \\
\text { content } \\
\text { (umolgitleaffresh } \\
\text { mass) }\end{array}$ & $0.68 \mathrm{c}$ & $03 \%$ & $41.69 \mathrm{a}$ & $126 \mathrm{c}$ & $4336 a$ & $2495 b$ & 110.50 & High & 28.58 & 8.87 & 7444 & High & 0.54 & 21.48 & 3416 & 90.69 & High \\
\hline  & $3293 \mathrm{~d}$ & $15.16 \mathrm{e}$ & $63.66 \mathrm{~b}$ & $30.12 \mathrm{~d}$ & $191.62 \mathrm{a}$ & $41.56 c$ & 10436 & High & 96.07 & 28.95 & 75.93 & High & 2405 & 46.89 & 11659 & 77.12 & High \\
\hline $\begin{array}{l}\text { Chlorophylla } \\
\text { content } \\
\text { (ugg'leaffiesh } \\
\text { masss })^{\circ}\end{array}$ & $135 \mathrm{~b}$ & $137 \mathrm{~b}$ & $138 \mathrm{~b}$ & $135 \mathrm{~b}$ & $1.97 \mathrm{a}$ & $1.45 \mathrm{~b}$ & 1648 & Low & 1.57 & 139 & 845 & Low & 136 & 137 & 1.71 & 1357 & Low \\
\hline $\begin{array}{l}\text { Chlorophyllb } \\
\text { content } \\
\text { (ugg' leaffiresh } \\
\text { mass) }\end{array}$ & $0.87 \mathrm{c}$ & $0.18 \mathrm{~d}$ & $0.92 \mathrm{~b}$ & 021d & $1.05 a$ & $0.26 \mathrm{~d}$ & 69.62 & Medium & 0.95 & 022 & 8874 & High & 0.53 & 0.57 & 0.66 & 11.45 & Low \\
\hline $\begin{array}{l}\text { Contentoffice } \\
\text { phenolics } \\
\text { (mgg'tleaffresh } \\
\text { mass) }\end{array}$ & 21ld & $1.6 \mathrm{~d}$ & 21ld & $641 \mathrm{c}$ & $10.43 a$ & $8.4 \mathrm{~b}$ & 7286 & Medium & 488 & 5.50 & 836 & Low & 1.86 & 426 & 9.45 & 7475 & High \\
\hline $\begin{array}{l}\text { Contentofoell } \\
\text { wall-linked } \\
\text { phenolics(mgg' } \\
\text { leaf } \\
\text { freshmass) }\end{array}$ & 791d & $881 \mathrm{c}$ & $1037 \mathrm{~b}$ & $8.8 \mathrm{c}$ & $1233 a$ & $11.92 \mathrm{a}$ & 18.09 & Low & 1020 & 9.85 & 252 & Low & 836 & 9.59 & 12.13 & 19.15 & Low \\
\hline
\end{tabular}

to liquid nitrogen, according to their "high" OCV. The effects of liquid nitrogen exposure on chlorophyll a and total chlorophyll concentrations, as well as, on contents of free phenolics were classified as "medium". Again, these indicators with "high" OCV are the most relevant effects for plant physiologists.

The combined effects of plant genetic transformation and the time of hardening are shown in Table 2. Calculation of the OCV allowed identifying the most relevant effects of the interaction of the two experimental factors: "high" OCV were found in the levels of malondialdehyde and other aldehydes. In the factor "type of plant material", the most significant effects were observed in the contents of malondialdehyde, other aldehydes and chlorophyll $b$. In the factor "time of in vitroplantlet hardening", "high" OCV were recorded in the levels of malondialdehyde, other aldehydes and free phenolics. The above mentioned indicators are the most relevant from the biological perspective.

We have previously used the OCV to identify the most relevant effects of experimental treatments in plant breeding (Gomez-Pando et al., 2009; Pérez et al., 2012), biofertilization (González et al., 2010; González et al., 2013), cryopreservation (Cejas et al., 2012; Cejas et al., 2013; Zevallos et al., 2013a; Zevallos et al., 2013b) and production of natural products (Pérez et al., 2013). To the best of our knowledge, a similar procedure has not been reported to date. The proposed method is quite simple and could be useful in practice - mostly in initial experiments in which a large number of variables are studied providing a quantitative and relatively objective procedure to focus the analysis of the results, and further research, on a limited number of parameters, which are more likely to reflect the most relevant responses of the plants to the specific treatment applied.

\section{Acknowledgments}

This work was supported by the Bioplant Centre (University of Ciego de Avila, Cuba). We are grateful to Mrs. Mayda Arzola, Mrs. Julia Martínez, Mrs. Alitza Iglesias, Mrs. Bárbara Valle, Mrs. Laritza Torreblanca, Ms. Melissa Arguedas, Mr. Orleans González, Dr. Aurora Pérez, Dr. Martha Hernández, Dr. Carlos Aragón, Dr. Ariel Arencibia, Dr. Marcos Edel Martínez, Mr. Arnaldo Trujillo, Mrs. Leyanes Díaz-López, Mr. Carlos Leiva and Mr. Gustavo Llorente. This research was also partially supported by the Australia Award Fellowship through a grant to Dr. José Carlos Lorenzo Feijoo.

\section{References}

Abdi H (2010). Coefficient of variation, p.1-5. In: Salkind N (Ed). Encyclopedia of Research Design. Thousand Oaks, CA, Sage.

Bradford MM (1976). A rapid and sensitive method for the quantification of microgram quantities of protein utilising the principle of protein-dye binding. Analyt Biochem 72:248-254.

Cejas I, Vives K, Laudat T, González-Olmedo J, Engelmann F, Martínez-Montero ME, Lorenzo JC (2012). Effects of cryopreservation of Phaseolus vulgaris L. seeds on early stages of germination. Plant Cell Rep 31:2065-2073. 
Cejas I, Méndez R, Villalobos A, Palau F, Aragón C, Engelmann F, Carputo D, Aversano R, Martínez ME, Lorenzo JC (2013). Phenotypic and molecular characterization of Phaseolus vulgaris plants from non-cryopreserved and cryopreserved seeds. Am J Plant Sci 4:844-849.

Espinosa P, Lorenzo JC, Iglesias A, Yabor L, Menéndez E, Borroto J, Hernández L, Arencibia A (2002). Production of pineapple transgenic plants assisted by temporary immersion bioreactors. Plant Cell Rep 21:136-140.

Gomez-Pando L, Jimenez-Davalos J, Eguiluz-de la Barra A, Aguilar-Castellanos E, Falconí-Palomino J, Ibañez-Tremolada M, Varela M, Lorenzo JC (2009). Field performance of new in vitro androgenesis-derived double haploids of barley. Euphytica 166:269-276.

González R, Laudat T, Arzola M, Méndez R, Marrero P, Pulido LE, Dibut B, Lorenzo JC (2011). Effect of Azotobacter chroococcum on in vitro pineapple plants' growth during acclimatization. In Vitro Cellular \& Developmental BiologyPlant 47(3):387-390.

González R, Serrato R, Molina J, Aragón C, Olalde V, Pulido L, Dibut B, Lorenzo JC (2013). Biochemical and physiological changes produced by Azotobacter chroococcum (INIFAT5 strain) on pineapple in vitro-plantlets during acclimatization. Acta Physiol. Plant. DOI: 10.1007/s11738-013-1373-z.

Gurr S, McPherson J, Bowles D (1992). Lignin and associated phenolic acids in cell walls, 51-56. In: Wilkinson DL (Ed). Molecular Plant Pathology. Oxford Press, Oxford.

Hammerschmidt R, Nuckleus E, Kuc J (1982). Association of enhanced peroxidase activity with induced systemic resistance of cucumber to Colletotrichum lagenarium. Physiol Plant Pathol 20:61-71.

Heath R, Packer J (1968). Photoperoxidation in isolated chloroplast: I. Kinetics and stoichiometry of fatty acid peroxidation. Arch Biochem Biophys 125:189-198.

ISTA (2005). International Rules for Seed Testing International Seed Testing Association, Bassersdorf, Switzerland, 35 p.

Ivanov Z (1989). The Agricultural Experimentation Pueblo y Educación, Havana, 332 p.
Martínez-Montero ME, Mora N, Quiñones J, González-Arnao MT, Engelmann F, Lorenzo JC (2002). Effect of cryopreservation on the structural and functional integrity of cell membranes of sugarcane (Saccharum sp.) embryogenic calluses. Cryoletters 23:237-244.

Pérez A, Laudat T, Mora M, Carvajal C, Aragón C, González J, Escalona M, Daquinta M, Trujillo R, Hernández M, Lorenzo JC (2013). Micropropagation of Hohenbergia penduliflora (A. Rich.) Mez. for sustainable production of plant proteases. Acta Physiol Plant 35(8):2525-2537.

Pérez G, Yanez E, Mbogholi A, Valle B, Sagarra F, Yabor L, Aragón C, González J, Isidrón M, Lorenzo JC (2012). New pineapple somaclonal variants: P3R5 and Dwarf. Am J Plant Sci 3:1-11.

Porra R (2002). The chequered history of the development and use of simultaneous equations for the accurate determination of chlorophylls a and b. Photosynth Res 73:149-156.

Standwood P, Bass L (1981). Seed germplasm preservation using liquid nitrogen. Seed Sci Technol 9:423.

Yabor L, Arzola M, Aragón C, Hernández M, Arencibia A, Lorenzo JC (2006). Biochemical side effects of genetic transformation of pineapple. Plant Cell Tiss Org Cult 86:6367.

Yanes PE, González J, Sánchez R (2000). A technology of acclimatization of pineapple vitroplants. Pineap News 7:24.

Zevallos B, Cejas I, Valle B, Yabor L, Aragón C, Engelmann F, Martínez ME, Lorenzo JC (2013a). Short-term liquid nitrogen storage of wild tomato (Solanum lycopersicum Mill.) seeds modifies the levels of phenolics in 7 day-old seedlings. Sci Hort 160:264-267.

Zevallos B, Cejas I, Rodríguez RC, Yabor L, Aragón C, González J, Engelmann F, Martínez ME, Lorenzo JC (2013b). Biochemical characterization of Ecuadorian wild Solanum lycopersicum Mill. plants produced from non-cryopreserved and cryopreserved seeds. CryoLetters 34:413-421. 